* Corresponding author Phone +421556024357 E-mail address: nataliajasminska@tuke.sk (Ing. Natália Jasminská, PhD.)

Article information Article history: AMS-Volume16-No.1-00150-12 Received 15 January 2012

Accepted 15 July 2012

\section{Opportunities and Limitations of Gasification of Peat in Plasma Reactor}

\author{
Kurilla Peter', Jasminská Natália ${ }^{2}$, Horbaj Peter ${ }^{2}$ \\ 'SAFINA, a. S., Plasma Process \& Technology, Jesenice, Czech republic \\ ${ }^{2}$ Faculty of Mechanical Engineering, Technical University in Kosice, Department of Power Engineering, Vysokoškolská 4, 04200 Košice, Slovak \\ Republic
}

\section{BIOGRAPHICAL NOTES}

Ing. Peter Kurilla, PhD. he is a graduate of Faculty of Mechanical Engineering, Technical University in Kosice (TUKE). Currently works at SAFINA, a. s., Plasma Process \& Technology. He actively participates in research of plasma technology, thermodynamics resources and mathematical modelling of energy processes.

Ing. Natália Jasminská, PhD. a graduate of Thermal energetics at the Faculty of Metallurgy of the Technical University in Košice. Currently she works at the Department of Power Engineering at the Faculty of Mechanical Engineering of TU Košice as a lecturer. During her PhD studies at the Faculty of Mechanical Engineering she took part in solving research tasks and grant projects where she currently works as a co-solver. Within solving research projects she is the author of more than 60 original publications in national and international magazines and text books. She actively participates in research of hydrogen technology, heat pump and of heat transfer

of energy processes.

prof. Ing. Peter Horbaj, PhD. He is professor of Department of power Engineering, Faculty of Mechanical Engineering, Technical University in Kosice. He is author and co-author of 7 textbooks, co-author of 1 patent and author or co-author 305 papers published in many domestics and international journals or presented on various international conferences. His research and project works focus to energy utilization of waste treatment, impulse burner, biogas station, utilization of wood chips, was awared by seferal prices.

\section{KEY WORDS}

Gasification, plasma reactor, peat, syngas, cogeneration unit.

\section{ABSTRACT}

This article analyzes the gasification process of peat mass for the large-scale devices and it discusses consequent utilization of the synthesis gas in terms of recovering energy of this gas in a cogeneration unit. The experiment was realized in $80 \mathrm{kVA}$ plasma reactor with dependent plasma arc. The nitrogen was used as inert gas to a plasma arc created. The main aim of these experiments was the generation energy efficiently, reducing the time required to destroy molecules of the treated waste, the elimination of emissions and streamline of the degradation process Compared to the conventional methods of thermal processing.

\section{Introduction}

Currently, the development of energy from renewable energy sources is extremely important [1]. Need of production of clean and efficient energy directed the inter- 
est of research and development centers in the area of plasma gasification technology. Attempts at the practical usage of plasma technology in the field of energy recovery of various materials were made on the ground of research workplaces. The primary purpose of these experiments was to generate energy efficiently, reduction of the time required for the destruction of the molecules of the treated waste, elimination of emissions and making the process of decomposition more effective in comparison with conventional methods of thermal processing. The major progressions in the field of gasification of selected types of materials were reached by the countries listed in Table 1 .
Promising ways of processing of organic substances in the combustible gases to generate heat and electricity are the methods of high temperature gasification. The raw material for gasification can be wood, peat, agricultural residues, as well as coal, whose reserves are great. Moreover, the methods of gasification of wood residues, peat, and coal are similar.

Peat, secondary energy resources are of considerable interest for energy in countries such as Russia, Belorussia, Finland, Poland, USA and so on. In Finland there are several operating district heating stations based on the updraft gasification of sod peat or wood waste.

Table 1: Overview of countries with dominant position in the plasma gasification depending on the type of gasified input material

\begin{tabular}{|c|c|c|c|c|c|c|}
\hline Biomass & Wood & Peat & Black liqour & $\begin{array}{l}\text { Municipal } \\
\text { waste }\end{array}$ & $\begin{array}{l}\text { Agricultural } \\
\text { waste }\end{array}$ & Sludge \\
\hline USA & USA & Finland & USA & USA & USA & USA \\
\hline Japan & Japan & USA & Sweden & Japan & Greece & Japan \\
\hline \multirow[t]{2}{*}{ China } & & & Finland & & Turkey & \\
\hline & & & & & Spain & \\
\hline
\end{tabular}

\section{Properties of peat}

Peat is partially petrified (fossilized) plant substance, usually of dark brown colour. It is generated in insufficiently oxygenated wetlands where the speed of accumulation of plants into structures of wetland is faster than decomposition processes. It is a complex material, a mixture of organic materials consisting of two dominant components, of lignite and cellulose. The properties of peat affect the factors of environment and dominant conditions in individual peat deposits.

The interaction of these conditions decides the type of peat bog. Representation of the chemical elements concentrated in peat $(\mathrm{Ba}, \mathrm{Ca}, \mathrm{Cd}, \mathrm{Co}$, $\mathrm{Cr}$, Fe, $\mathrm{La}, \mathrm{Mn}, \mathrm{Ni}, \mathrm{Ti}, \mathrm{Zn}, \mathrm{Al}, \mathrm{Be}, \mathrm{Cu}, \mathrm{Pb}, \mathrm{Mg}, \mathrm{Na}$ ) is variable in dependence on the depth of the peat placement layer. Generally, it can be stated that this is a highly porous material with a low density of about $200 \mathrm{~kg} \cdot \mathrm{m}^{-3}$. It is used e.g. to remove pollutants from wastewater without further pretreatment or for energy purposes. The sorption ability of peat can be adversely affected by characteristics, such as low mechanical strength, high affinity of peat with water, poor chemical stability or the tendency of decrease and increase of volume.

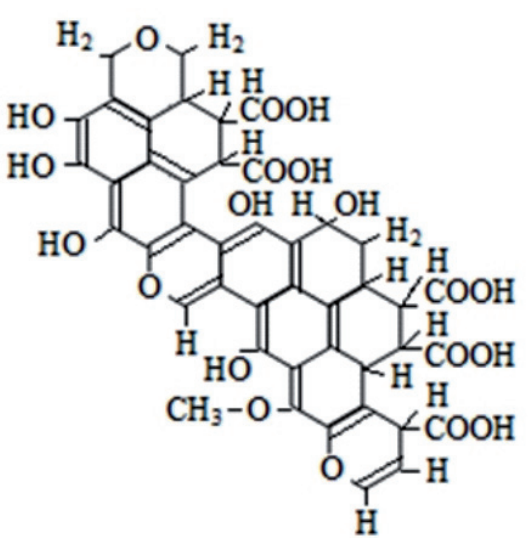

Fig. 1: The cell structure of peat.

The interaction of these conditions decides the type of peat bog. Representation of the chemical elements concentrated in peat $(\mathrm{Ba}, \mathrm{Ca}, \mathrm{Cd}, \mathrm{Co}$ $\mathrm{Cr}, \mathrm{Fe}, \mathrm{La}, \mathrm{Mn}, \mathrm{Ni}, \mathrm{Ti}, \mathrm{Zn}, \mathrm{Al}, \mathrm{Be}, \mathrm{Cu}, \mathrm{Pb}, \mathrm{Mg}, \mathrm{Na}$ ) is variable in dependence on the depth of the peat placement layer. Generally, it can be stated that this is a highly porous material with a low density of about $200 \mathrm{~kg} \cdot \mathrm{m}-3$. It is used e.g. to remove pollutants from wastewater without further pretreatment or for energy purposes. The sorption ability of peat can be adversely affected by characteristics, such as low mechanical strength, high affin- 
ity of peat with water, poor chemical stability or the tendency of decrease and increase of volume. The percentage representation of organic substances in dry mass represents the value over $50 \%$. Countries with rich supplies of peat bogs (Finland, Russia, USA) use this source of fossil fuel in energy industry to produce electricity and heat by combustion. Molecular structure of lignite, cellulose and cell structure itself are shown in Fig. 1 and Fig. 2 [3].

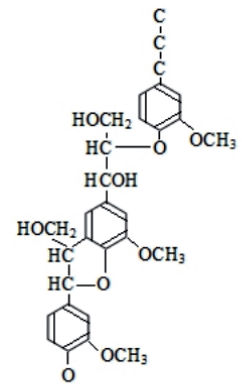

LIGNITE

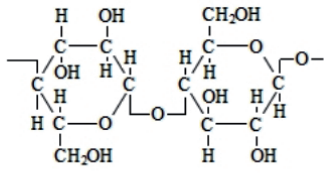

CELLULOSE
Fig. 2: Molecular structure of lignite and cellulose [3].

Based on the species representation of atoms in the molecular structure, it can be assumed positive development of combustible gaseous components generation $\left(\mathrm{H}_{2}, \mathrm{CO}\right)$ in the synthesis gas $[10,11]$. Moisture contained in the fuel charge at gasification of peat can greatly contribute to the favourable ratio of $\mathrm{C} / \mathrm{O}$ in the reaction chamber of plasma reactor.

On the other hand, the excess of oxygen may give rise to charcoal. The gasification test of wood (structure similar to peat) carried out at the Technical University of Košice - Department of Power Engineering can be given as an example.

\section{Charakteristics of plasma devices}

Experimental gasification of peat was done in 80 kVA DC plasma reactor with dependent electric arc with a hot empty graphite electrode which is shown in Fig. 3. The charge of the processed waste was ensured through the charging device (snail conveyor belt) with possibility of continuous charging of waste of grain size $<5 \mathrm{~mm}$. The gasification process was conducted in a reduction vacuum atmosphere, 0.05 to $0.1 \mathrm{kPa}$ [2]. The plasma arc is generated between an empty graphite electrode placed centrally in the arch of the plas- ma reactor (cathode) and graphite crucible which forms the bottom of the reactor (anode). The produced synthesis gas is drained through drain hole of syngas, built in the arch of the reactor towards to the cyclone which makes the first stage of synthesis gas cleaning circuit. Tapping hole is placed in a graphite crucible near the bottom of the plasma reactor. The reactor envelope is cooled by air with the exception of the arch $[4,5,6]$.

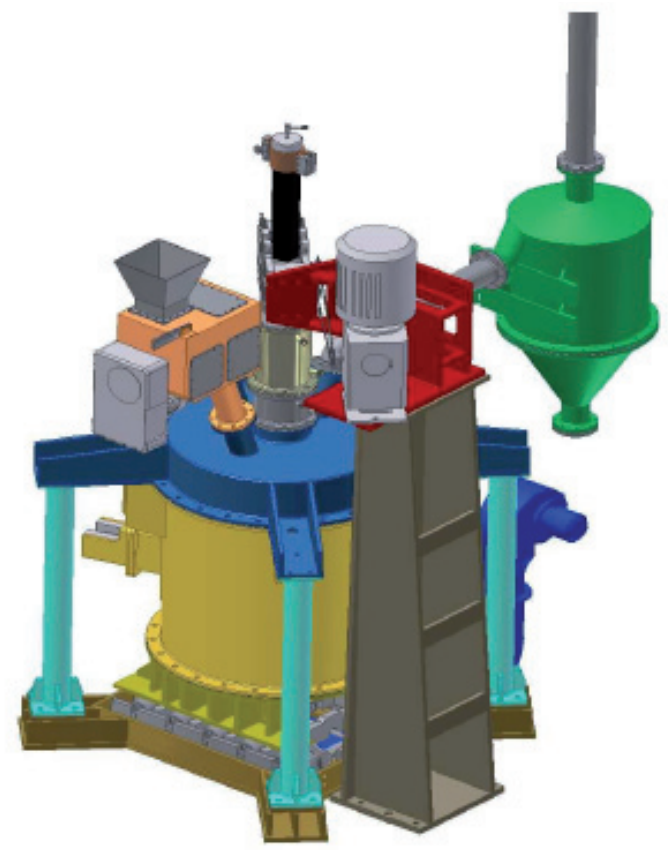

Fig. 3: 3D scheme of 80 kVA plasma reactor.

The transfer of inert or another type of gas into the plasma state is accompanied by various processes of interaction between particular particles of gas. These processes are mainly characterized by the interactions of - particle collisions or interactions of particles with radiation and lead to an increase of internal energy. Transformation of gaseous medium into the plasma state in a plasma burner is accompanied by processes of excitation, dissociation and ionization whereas high energy flux in the form of thermal energy is produced. Due to the high heat flux emitted from the plasma arc, destruction of the processed material, generation of simple gaseous components and minimization of output solid components from the process are given rise. Basic mechanisms of heat transfer concerned with the heating and melting of particles in a plasma gasification when a particle is in contact 
with the plasma arc are presented schematically in Fig. 4. Energy contributing to the heating and melting of particles (Qn) can be expresses as the difference between the energy transfer by conduction and convection from plasma to particles and radiation energy $[6,9]$ emitted from the surface into the surroundings.

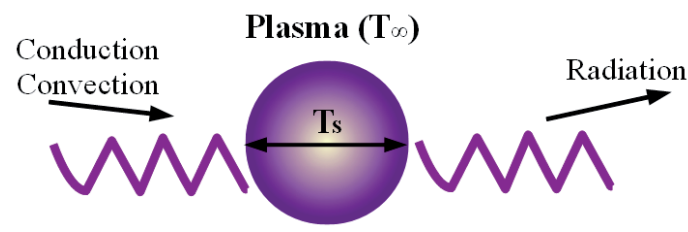

Fig. 4: Simplified mechanisms of heat transfer concerned with the heating and melting of particles.

$$
Q_{n}=k . S .\left(T_{\infty}-T_{s}\right)-\sigma . \varepsilon . S .\left(T_{s}^{4}-T_{a}^{4}\right)(W)(1)
$$
where: $k$ the heat transfer coefficient of plasma particle $\left(\mathrm{W} \cdot \mathrm{m}^{-2} \cdot \mathrm{K}^{-1}\right), S$ - surface area of particle $\left(\mathrm{m}^{-2}\right), T_{\infty}$ temperature of plasma (K), $T_{s}$ - temperature of the particle surface $(K), T_{a}$ temperature of the reactor's wall $(\mathrm{K}), \sigma$-Stephan-Boltzmann constant $\left(\mathrm{W} \cdot \mathrm{m}^{-2} \cdot \mathrm{K}^{-4}\right)$, $\varepsilon$ - emissivity of particles (-).

Equation (1) represents simplified description of the mechanisms of heat transfer taking place in the early stages of decomposition process. In the further stages, the change of mechanisms of heat transfer is caused by formation of a gaseous curtain around the particle due to surface evaporation which will limit the heat transfer $[7,8]$.

\section{Experimental measurement}

Measurements in accordance with standards BS EN 14774-2 for determination of moisture content in the fuel were carried out before the gasification process. The results showed that the moisture content in the analyzed type of peat in area of $15 \mathrm{vol}$. \% (Table 2).

The analyzed type of peat (origin Belarus) in the original condition showed grain size from 5 to 150 $\mathrm{mm}$. Coarse-grained structure of the original sam- ple did not meet the parameters corresponding to the technical requirements of the charging device, so the fuel charge was adjusted by manual crushing to the grain size 0-5 $\mathrm{mm}$. Viewpoint at the samples analyzed before and after reduction are shown in Fig. 5.

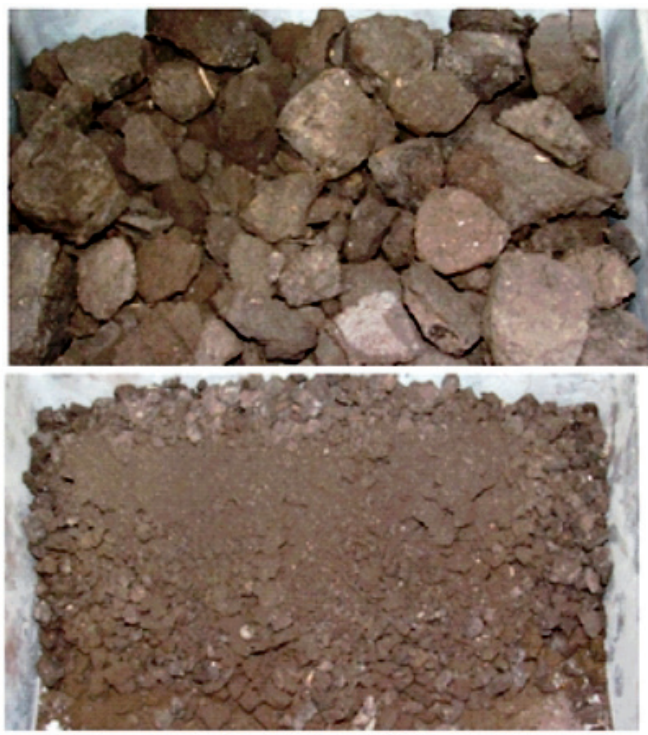

Fig. 5: Sample of peat in the original state and after crushing.

Total time of charging was 170 minutes at consumption of $14.5 \mathrm{~kg}$ of inlet peat. Amount of generated syngas during the gasification process corresponded to volume 30 to $35 \mathrm{Nm}^{3} \cdot \mathrm{h}^{-1}$ at steady sample charging of $5.12 \mathrm{~kg} \cdot \mathrm{h}^{-1}$.

Volume percentage of the three most dominant components of generating syngas in dependence on time is shown in Fig. 6

Synthesis gas (a mixture of gases produced in the process of decomposition of the sample + the nitrogen used in the plasma burner) leaving the reaction zone of the plasma reactor went through the phases of cooling, cleaning, neutralization, and then it was burnt altogether with natural gas in cogeneration unit with microturbine. The average lower a gasification depending on the type of gasified input material.

\begin{tabular}{|lllll}
\hline Identifications of the sample & $\begin{array}{l}\text { Weight before drying } \\
\mathbf{( g )}\end{array}$ & $\begin{array}{l}\text { Weight after drying } \\
\mathbf{( g )}\end{array}$ & $\begin{array}{l}\text { Temperature of drying } \\
\text { ('C) }\end{array}$ & $\begin{array}{l}\text { Humidity (Vol.\%) } \\
\text { RB-1* }\end{array}$ \\
\hline 6,446 & 5,500 & $105 \pm 2$ & 14,676 \\
RB-2 $^{*}$ & 3,318 & 2,800 & $105 \pm 2$ & 15,612
\end{tabular}

${ }^{*} \mathrm{RB}-1, \mathrm{RB}-2$ - specifications of the analysed peat sample. 
calorific value of the produced gas was set to 3.0 to $3.5 \mathrm{MJ} \cdot \mathrm{Nm}^{3}$ which corresponds to the energy value from 0.8 to $1.0 \mathrm{~kW} \cdot \mathrm{Nm}^{3}$ at the given conditions. Solid residues leaving the gasification process in the form of slag and entrained dust captured in the cyclone separator did not undergo the detailed analysis.

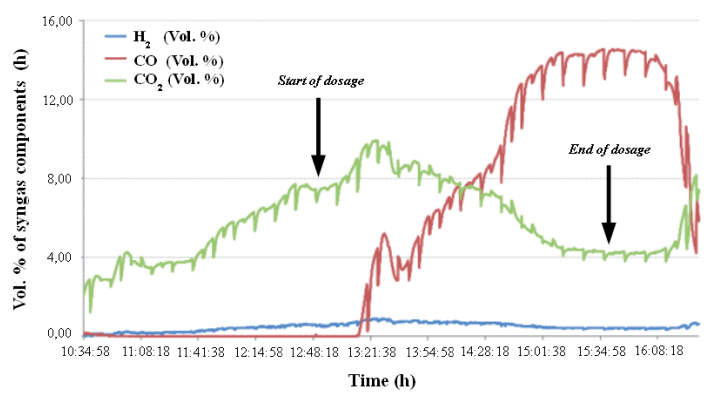

Fig. 6: Development of selected components of synthesis gas generation.

The total amount of captured entrained dust in the cyclone was at value of $15 \%$ of charge. Practically, the slag from the charge was not created.

Rate of natural gas substitution during continuous charging of peat for the time interval of 170 minutes while maintaining stable electrical performance of cogeneration unit is shown in Fig. 7.

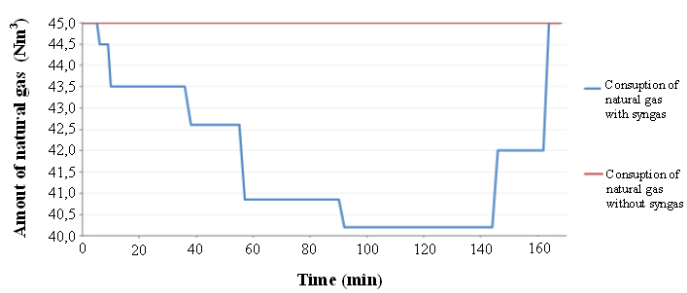

Fig. 7: Consumption of natural gas during peat gasification.

\section{Discussion}

Based on the results obtained from gasification of peat in reduction atmosphere of selected type of experimental reactor (at comparison of energy intensity of gasification process and energy value of gained syngas) at the above-defined conditions of gasification, it is not economically profitable. Low percentage of combustible components of syngas $\mathrm{H}_{2}$ and $\mathrm{CO}$ and high content of nitrogen, used for generation of the plasma column of volume of 8.5 to $10 \mathrm{~N} / \cdot \mathrm{min}^{-1}$, take significant share in low average value of lower calorific value of the obtained gaseous medium which is in range of 3.0 to $3.5{\mathrm{MJ} \cdot \mathrm{Nm}^{-3}}^{-3}$ in this case. Based on these results, the total conver- sion of organic mass of charge on individual components of syngas can be assumed.

\section{Conclusion}

Based on data contained in various world publications, higher percentage of combustible components $\left(\mathrm{CO}\right.$ and $\mathrm{H}_{2}$ ) in the synthesis gas at the gasification of waste biomass and peat can be predicted by application of another mode of plasma reactor operation. The used type of plasma burner affects the parameters of the plasma column significantly and the type of operational atmosphere of reactor (inert, oxidizing) takes share in ratio of gaseous and solide products leaving the plasma gasification process.

List of symbols and abbreviations:

DC - direct current (DC);

RB-1 - specification of the analysed peat sample;

RB-2 - specification of the analysed peat sample.

\section{Acknowledge}

The article was created thanks to the support of the agency of the Ministry of Education, Science, Research and Sport of the Slovak Republic for structural funds of the EC of the operational program "Research and development", project no. ITMS 26220220044.

\section{References}

[1] Arjan F. Kirkels, Geert P. J. Verbong Biomass gasification: Still promising? A 30-year global overview In Renewable and Sustainable Energy Reviews, 2011, vol. 15, issue 1, p. 471 481.

[2] Brestovič, T., Lázár, M. Návrh Thomasovho valca pre meranie malých prietokov dusíka v plazmovom reaktore. In: 29. Setkáni kateder mechaniky tekutin a termomechaniky: mezinárodní konference : 23. - 25. 6. 2010, Rožnov pod Radhoštem. - Ostrava : VŠB-TU, 2010 P. 13-16. - ISBN 978-80248-2244-0.

[3] Couillard, D. The use of peat in wastewater treatment. In Water Research, 1994, vol. 28, p. 1261 - 1274.

[4] Imriš, I., Klenovčanová, A., Molčan, P. Thermal decomposition of waste in plasma reactor. In 6th Conference on Environment and Mineral Processing, Ostrava: Hornicko-Geologicka fakulta VSB TU Ostrava, Czech Republic, 2002. ISBN 80-248-0071-3.

[5] Interný materiál združenia PlazmaGroup, Bardejov 2010.

[6] Ivančo, V., Kubín, K., Brestovič, T. Fire resistance assessment of containers for transport of radioactive waste. In: ICMT'11 
proceedings of the International Conference on Military Technologies 2011 : Brno, Czech Republic, 10 to 11 May, 2011. - Brno: University of Defence, 2011 P. 1481-1486. ISBN 978-80-7231-787-5

[7] Rutberg, G. Ph. at col. On efficiency of plasma gasification of wood residues, In Biomass and Bioenergy, 2011, vol. 35, issue 1, p. $495-504$

[8] Tendero, C. et. al. Atmospheric pressure plasmas. In Spectrochimica Acta Part B, 2006, vol. 61, p. 2 - 30.

[9] Fodor, P., Urban, F. Technicko-ekonomické modelovanie prevádzky energetických strojov a zariadení. In: 30. Setkání kateder mechaniky tekutin a termomechaniky: sborník přispěvků. Špindlerův Mlýn, 22. -24. 6. 2011. Liberec: Technická univerzita v Liberci, 2011. ISBN 978-80-7372-747-5. - s. 33-36.

[10] Muránsky, J., Badida, M. Environmental Compatibility of Mechanical Engineering Products. In: Acta Mechanica Slovaca. Vol. 14, No. 1/2010, s. 72-75, ISSN 1335-2393.

[11] Patkó, l., et al. Emission of dioxins in biomass using furnaces. In: Acta Mechanica Slovaca. Vol. 14, No. 1 (2010), s. 94-99. ISSN $1335-2393$.

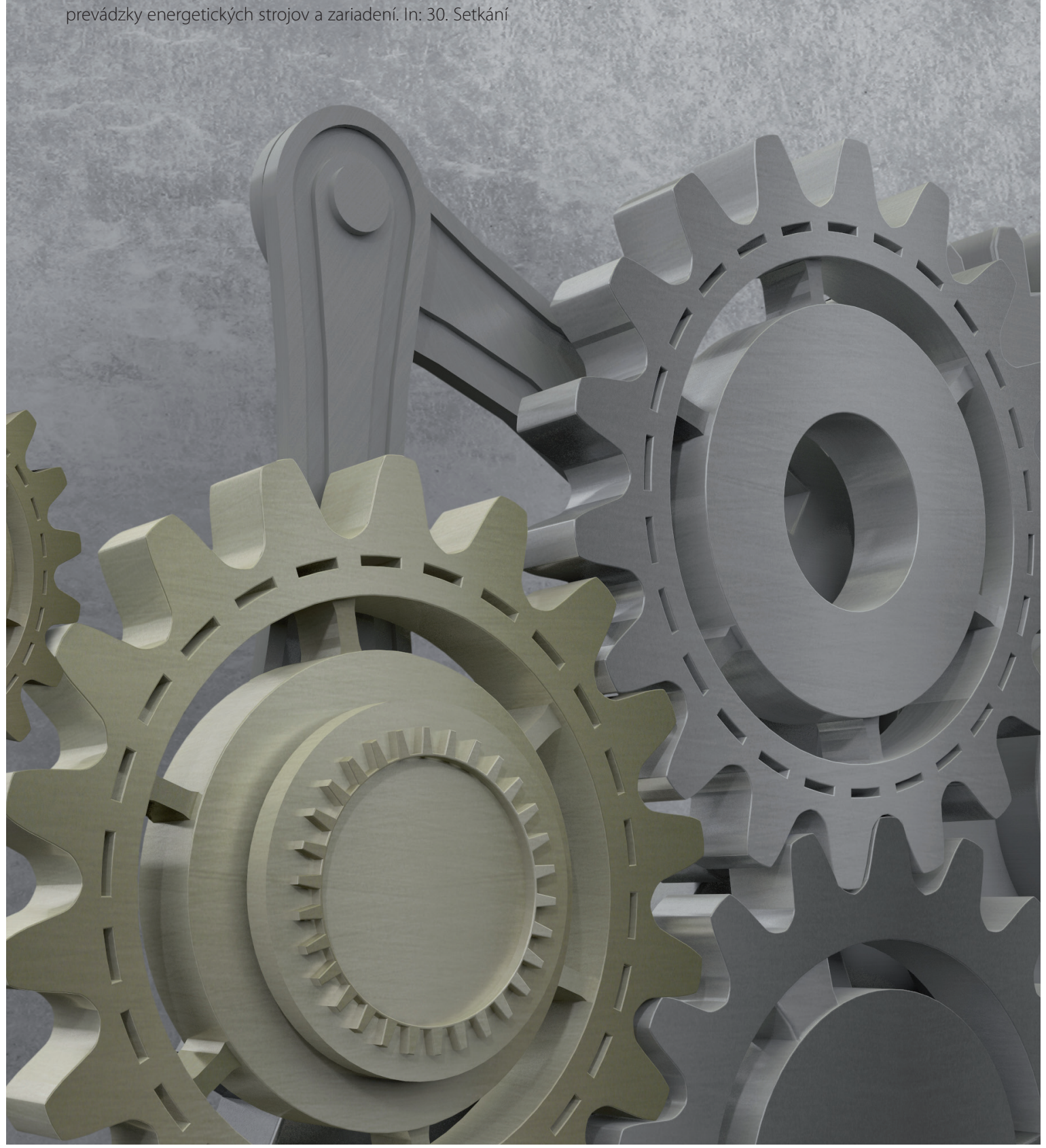

